\title{
Ethics of conducting the study "Oral $24 \%$ sucrose associated with nonnutritive sucking for pain control in healthy term newborns receiving venipuncture beyond the first week of life" [Response to Letter]
}

This article was published in the following Dove Press journal: Journal of Pain Research

\author{
Giuseppe De Bernardo' \\ Marina Riccitelli ${ }^{2}$ \\ Desiree Sordino' \\ Maurizio Giordano 3 \\ Sabrina Piccolo' \\ Giuseppe Buonocore ${ }^{2}$ \\ Serafina Perrone ${ }^{2}$ \\ 'Department of Emergency, NICU, \\ AORN Santobono-Pausilipon, Naples, \\ Italy; ${ }^{2}$ Department of Molecular and \\ Developmental Medicine, University of \\ Siena, Siena, Italy; ${ }^{3}$ Faculty of Medicine, \\ Federico II University, Naples, Italy
}

\section{Dear editor}

We are glad to respond to the concerns raised by Harrison and Bueno regarding our manuscript. Some mistakes and misunderstanding in the original letter need to be addressed. The surname of the first author is De Bernardo and not Bernardo. In our paper, 66 healthy newborns with a mean of 22 days of life were enrolled. This was the first novelty in the study design. Secondly, the patients were newborns discharged from hospital and readmitted for routine controls in the neonatal ward. The setting of the study was thus quite different from neonatal intensive-care units or rooming-in inpatients in the first days of life. The study aimed to test the effectiveness of sweet solutions associated with nonnutritive sucking in healthy and unhospitalized newborns. Newborns received oral $24 \%$ sucrose or $10 \%$ glucose before and during venipuncture, starting with a pacifier for nonnutritive sucking in both groups. The authors did not limit their analysis to effectiveness of the sweet solutions as nonpharmacological treatment, but they studied the efficacy of the sweet solutions in association with nonnutritive sucking in the neonatal period, during the third week of life, and in a new setting. For this reason, the study complied with the principle of equipoise. Our research team have already performed several studies on neonatal pain. ${ }^{1-8}$ We are sorry that we did not cite the work of Harrison and Bueno, but the list of references reported in the manuscript was adequate for the aim of the study. In a meta-analysis, Harrison et al considered eligible 62 trials that included

\footnotetext{
term and/or preterm infants in the neonatal period, receiving sucrose, glucose, or other sweet solutions orally compared with no treatment, water, pacifier, swaddling/positioning, skin-to-skin care, formula feeding, expressed breast milk, breastfeeding, sensorial saturation, or topical anesthetics. ${ }^{9}$
}

Furthermore, this meta-analysis focused only on crying time and composite infant painintensity scores to evaluate the effectiveness of nonpharmacological treatments. Our study aimed to investigate the use of sweet solutions in association with nonnutritive
Correspondence: Serafina Perrone Department of Molecular and

Developmental Medicine, University of Siena, 36 Viale Bracci, Siena 53100, Italy

Tel +390577586542

Fax +390577586182

Emailsaraspv@yahoo.it
Journal of Pain Research 2019:12 1915-1916

1915

(c) (i) 2019 De Bernardo et al. This work is published and licensed by Dove Medical Press Limited. The full terms of this license are available at https://www.dovepress.com/ BY terms.php and incorporate the Creative Commons Attribution - Non Commercial (unported, v3.0) License (http://(creativecommons.org/licenses/by-nc/3.0/). By accessing the work you hereby accept the Terms. Non-commercial uses of the work are permitted without any further permission from Dove Medical Press Limited, provided the work is properly attributed. For permission for commercial use of this work, please see paragraphs 4.2 and 5 of our Terms (https://www.dovepress.com/ttrms.php). 
sucking in the neonatal period (0-29 days) beyond the first 2 weeks of life in healthy unhospitalized newborns who returned to the clinic for checkup and had venipuncture requested. ${ }^{10}$ Parents were fully informed about the aims of the study, and they were also able to choose to provide their newborn breastfeeding, nonnutritive sucking, or sweet solutions alone during venipuncture. To the best of our knowledge, this is the first study in the literature to investigate the efficacy of $24 \%$ sucrose as an analgesic in healthy unhospitalized newborns in the third week of life. This research reduces the gap in health assistance during the neonatal period. A pilot study can be also a way to implement nonpharmacological treatment to control pain in newborns in settings other than intensive-care units. Despite evidence existing on the efficacy of sweet solutions since the 2000s, it is still not routine analgesic procedure in neonatal care.

In conclusion, the study contributes to reducing the gap between theory and clinical practice and paves the way to encourage and implement the best clinical practice for newborns.

\section{Disclosure}

The authors report no conflicts of interest in this communication.

\section{References}

1. Bellieni CV, Buonocore G. Using the pain principle to provide a new approach to invasive treatments and end-of-life. Acta Paediatr. 2019;108(2):206-207.

2. Bellieni CV, Bagnoli F, Buonocore G. Alone no more: pain in premature children. Ethics Med. 2003;19(1):5-9.

3. Perrone S, Bellieni CV, Negro S,et al. Oxidative stress as a physiological pain response in full term newborns. Oxid Med Cell Longev. 2017;2017:375928. doi:10.1155/2017/3759287

4. Bellieni CV, Gabbrielli M, Tataranno ML, Perrone S, Buonocore G. Which legal consequences for those who provoke pain to infants. Minerva Pediatr. 2012;64(1):41-45.

5. Bellieni $\mathrm{CV}$, Iantorno $\mathrm{L}$, Perrone $\mathrm{S}$, et al. Even routine painful procedures can be harmful for the newborn. Pain. 2009;147(13):128-131. doi:10.1016/j.pain.2009.08.025

6. Bellieni CV, Cordelli DM, Marchi S, et al. Sensorial saturation for neonatal analgesia. Clin J Pain. 2007;23(3):219-221. doi:10.1097/ AJP.0b013e31802e3bd7

7. Bellieni CV, Bagnoli F, Perrone S, et al. Effect of multisensory stimulation on analgesia in term neonates: a randomized controlled trial. Pediatr Res. 2002;51(4):460-463. doi:10.1203/00006450-200204000-00010

8. Bellieni CV, Buonocore G, Nenci A, Franci N, Cordelli DM, Bagnoli F. Sensorial saturation: an effective analgesic tool for heel-prick in preterm infants: a prospective randomized trial. Biol Neonate. 2001;80(1):15-18. doi:10.1159/000047113

9. Harrison D, Larocque C, Bueno M, et al. Sweet solutions to reduce procedural pain in neonates: a meta-analysis. Paediatrics. 2017;139 (1):e20160955. doi:10.1542/peds.2016-0955

10. De Bernardo G, Riccitelli M, Sordino D, et al. Oral $24 \%$ sucrose associated with non-nutritive sucking for pain control in healthy term newborns receiving venipuncture beyond the first week of life. J Pain Res. 2019;12:299-305. doi:10.2147/JPR.S184504

Dove Medical Press encourages responsible, free and frank academic debate. The content of the Journal of Pain Research 'letters to the editor' section does not necessarily represent the views of Dove Medical Press, its officers, agents, employees, related entities or the Journal of Pain Research editors. While all reasonable steps have been taken to confirm the content of each letter, Dove Medical Press accepts no liability in respect of the content of any letter, nor is it responsible for the content and accuracy of any letter to the editor.

\section{Publish your work in this journal}

The Journal of Pain Research is an international, peer reviewed, open access, online journal that welcomes laboratory and clinical findings in the fields of pain research and the prevention and management of pain. Original research, reviews, symposium reports, hypothesis formation and commentaries are all considered for publication. The manuscript management system is completely online and includes a very quick and fair peer-review system, which is all easy to use. Visit http:// www.dovepress.com/testimonials.php to read real quotes from published authors. 